\title{
Low Temperature Oil for House Hold Applications Extracted from Simple Hand Driven Screw Pump
}

\author{
W.Porselvi, R.Vasuki, G.Anandhi
}

\begin{abstract}
The project work entitled "A STUDY ON HOMEMAKERS' BRAND PREFERENCE TOWARDS CONSUMPTION OF GINGELLY OIL" carried out by the researcher to know the homemakers' brand preference of gingelly oil. Prediction of individual preference is an elusive task, however, since it represents a fundamental step in understanding consumer choice. This study deals with how consumers' brand preference change on the variables of the product like price, quality, package, advertisement, satisfaction, taste, brand loyalty etc. It also deliberates the reasons for selecting the particular brand of gingelly oil and exile the highly preferable brand.

This study is supported by both primary and secondary data, where the primary data was compiled from questionnaire collected from 120 samples in Chennai. The data collected are processed through statistical tools. Then suggestions are given based on the findings (through statistical tools) for further improvement of the brand/product.
\end{abstract}

Key words: Consumer, preference, loyalty, perception, purchase.

\section{INTRODUCTION}

Promoting begins with buyer. So shopper is a big cheese to an advertiser. Individuals start to create inclination at a beginning time our inclination are a piece of what makes us what our identity is. The brands we search out mirror our inclinations. Shopper chooses what to buy, for whom to buy, for what reason to buy, from where to buy, and the amount to buy. So as to turn into an effective advertiser, he should know the enjoying or detesting of the clients.[1]-[5] He should

know the time and the amount of products and enterprises, a purchaser may buy, with the goal that he may store the merchandise or give the administrations as indicated by the likings of the buyers. Today the makers produce and the dealers sell whatever the purchaser likes. In this sense, "shopper is the preeminent in the market". Picking up and keeping up purchaser inclination is a fight that is rarely truly won. "Brand preference is the measure of brand loyalty in which a consumer will choose a particular brand in presence of competing brands". To study the brand preference of the consumer, it is essential to have a clear idea about, Consumer

Revised Manuscript Received on December 30, 2019.

W.Porselvi, Assistant Professor, Department Of Science and Humanities,Bharath Institution Of Higher Education And Research TamilNadu,India. Email: porselviwilson@gmail.com

R.Vasuki, Assistant Professor, Department Of Science and Humanities,Bharath Institution Of Higher Education And Research TamilNadu,India. Email: vasukiteacher@gmail.com

G.Anandhi Assistant Professor, Department of Science and Humanities,Bharath Institution Of Higher Education And Research TamilNadu,India. Email: anandhi5679@gmail.com buying decision process, Brand awareness of consumer, Factors influencing brand preference,Brand loyalty of consumers.

\section{NEED FOR THE STUDY}

It is essential to the producers to study over the consumer brand preference, to be successful in the market place.To know how price, quality, flavor, health factor, package and advertisement influence consumer in brand preference towards gingelly oil. To identify the loyal customers Manufacturers' are facing with variety of challenges. One main challenge is to monitor the changes in brand preference over time.

\section{OBJECTIVES OF THE STUDY}

To know the brand loyalty of consumers.

To know the reason for selecting particular brand gingelly oil.

To find the highly preferable brand of gingelly oil among the respondents.

To assess the satisfaction level of consumers.

\section{SCOPE OF THE STUDY}

This study reveals the brand preference of homemakers' towards gingelly oil. This study has been conducted among 120 homemakers'. This study also covers the satisfaction level of homemakers' and the perception towards variable attributes of the brand like price, package, quality, availability etc; This study is also intended to know the reason for selecting particular brand of gingelly oil and to know the brand loyalty of the consumers.

\section{RESEARCH PRODUCTS SUMMARY}

\section{A. V.V.V.Anandham Gingelly Oil:}

The enchantment to unadulterated Anandham will be Anandham Gingelly Oil - the equivalent word of satisfaction. The sesame seeds are regular yet at VVV Anandham and Sons simply the best mix of sesame seeds are looked over different states and prepared to give its striking brilliant shade, unique enthusiastic fragrance and select taste that shivers your tongue. The different states from which we get our sesame seeds are Tamil Nadu, 
Andra Pradesh, Gujarat, Karnataka, Madhya Pradesh, Maharashtra, Rajasthan, Uttar Pradesh and West Bengal. The sesame seeds at the VVV Anandham gingelly oil production line are mixed uniquely with palm jaggery. [6]-[10]

This conventional ALCHEMY achieves extraordinary quality and braces the body. At the manufacturing plant each cluster of Anandham gingelly oil is tasted by the CEO Mr. A. Mamallan at every single stage to guarantee simply the best arrives at the shopper. Since 1942 over 65 years Anandham gingelly oil has been of true support of the strength of every single Indian resident. Its virtue makes it an unequaled top choice.

Anandham gingelly oil in your kitchen is a mystery to Kayakalpa (Ever green energy) and an ever brilliant skin. Anandham gingelly oil when scoured into the body during Abyanga a type of Indian back rub it expands the vitality stream and liberates the assemblage of debasements. Since 1942, V.V.V.Anandham and Sons are the pioneers and pioneers in the consumable oil advertise. Its lead image is "V.V.V.Anandham sesame oil". On account of the brilliant quality, we are presently India's Most Preferred Brand.[11]-[14]

\section{B. Idhayam Gingelly Oil:}

Pro in - Branded sesame seed oil in India, selling more than 700 tons for each month-produced of predominant quality sesame seeds cleaned by a three level cleaning framework fabricated by specialists with 52 years of involvement with this field-best quality palm jaggery included the procedure likewise utilized in the arrangement of Ayurvedic meds.

\section{Piriyam Gingelly Oil:}

VVD built up in 1942 is pleased with its author's vision. Today, it stands declaration to the farsightedness of Shri. V.V.Dhanushkodi, as an organization that has become through unswerving duty to quality that has helped the organization unite a huge, , and faithful customer base over a multi year time frame.

VVD's contribution in the consumable oil class ranges VVD Gold and Pure Drops Coconut oil, Piriyam Gingelly Oil, Arogya Vegetable Blended Edible Sunflower Oil and Amla in addition to Brahmi Hair Oil.

VVD today, has rebuilt itself into an organization that has different interests-eatable oils, hair oils, account, shipping, warehousing stevedoring, moving, producing iodized salt and joining the utilization of minerals like gypsum and synthetic substances like initiated carbon for different mechanical purposes. The organization fabricates tin, polymer holders and layered boxes. VVD. A Group that continues developing to meet more up to date purchaser needs and accepts that a fulfilled shopper profile is progressively significant that the main concern of an accounting report. The VVD duty is additionally reflected in its present turnover of US \$ 7 million which is relied upon to contact the US $\$ 30$ million imprint by 2000AD. VVVD's 'Piriyam' gingelly oil is made of sesame seeds, a rich wellspring of sound fats that help in bringing down elevated cholesterol levels. Otherwise called sesame oil, it is generally utilized for cooking in Tamil nadu and other south Indian states. Known as till oil in the eastern pieces of India, it improves the digestion of the body and forestalls obstruction

\section{Anjali Gingelly Oil:}

"Adding grins and miles to your family".Anjali Oils and Foods were resulting from the fantasy of visionary business visionary, Mr. K.S.R.Natarajan. He was very much aware of the gigantic significance of sesame, or gingelly oil in the way of life of South India, and how it is utilized as a cooking medium, for therapeutic purposes in Ayurveda, and for restorative use. Understanding the potential significance of this healthfully rich oil in an undeniably wellbeing cognizant society, he established Nataraj Oil Mills Private Limited in 1994, to give the best quality gingelly oil to little and huge purchasers. Mr. Natarajan has risen as a pioneer in the oil business, with a solid foundation of around thirty years in the oil industry.[15]-[20] ' Anjali Oils and Foods' items are delivered in a completely computerized assembling plant along the Madurai-Chennai Highway in Tamil Nadu, India that is spread over a zone of 5 sections of land. Cutting edge hardware and top notch fixings guarantee quality items clinging to worldwide measures. The items are pressed totally immaculate by human hands during the whole procedure, and are along these lines guaranteed of a more drawn out time span of usability.[21]-[24]

\section{E. Svs Gingelly Oil:}

SVS oil mills produce gingelly oil and gingelly cake.

\section{METHODOLOGY}

Research is a serious academic activity with the set of objectives to explain or analyze or understand a problem or finding solutions for problems adopting a systematic approach in collecting, organizing and analyzing the information relating to a problem. The study was conducted in Chennai. 120 respondents were selected as sample to do this research. Descriptive research design is used for this study. Descriptive studies aim at portraying accurately the characteristics of a particular or situation. Descriptive studies involve hypothesis formulation and testing. The main characteristic of this method is that the researcher has no control over the variable; he can only report what has happened or what is happening.

\section{LIMITATIONS OF THE STUDY}

To confinement of time just 120 examples were chosen for the investigation. So the example of customers was insufficient to sum up the discoveries of the investigation.

The fundamental wellspring of information for the investigation was essential information with the assistance of self-managed surveys. Subsequently, the odds of fair data are less. Individuals were reluctant to reveal the verifiable realities 


\section{RESULTS AND DISCUSSIONS}

Ranking The Factors Considered By The Respondents

\section{While Selecting Particular Brand Gingelly Oil}

\begin{tabular}{|c|c|c|c|c|c|c|c|c|c|c|c|}
\hline \multirow{2}{*}{ S.No } & \begin{tabular}{|l|l} 
Factors \\
\end{tabular} & & II & II & IIII & $\overline{I V}$ & $\overline{\mathrm{V}}$ & $\sqrt{\mathrm{VI}}$ & \multirow{2}{*}{ Total } & \multirow{2}{*}{ Score } & \multirow{2}{*}{ Rank } \\
\hline & \begin{tabular}{|l|} 
Weights \\
\end{tabular} & WW & $\overline{86}$ & 5 & 4 & 3 & 2 & 1 & & & \\
\hline 1. & \begin{tabular}{|l||} 
Better \\
Quality
\end{tabular} & \begin{tabular}{|l||}
$x$ \\
$y x$
\end{tabular} & $\begin{array}{l}5 \\
30\end{array}$ & $\begin{array}{l}17 \\
85\end{array}$ & $\begin{array}{l}17 \\
68\end{array}$ & $\begin{array}{l}18 \\
54\end{array}$ & $\begin{array}{l}27 \\
54\end{array}$ & $\mid \begin{array}{l}36 \\
36\end{array}$ & $\begin{array}{l}120 \\
327\end{array}$ & 2.725 & VI \\
\hline 2. & $\begin{array}{l}\text { Fair } \\
\text { Price }\end{array}$ & \begin{tabular}{l||}
$\mathrm{x}$ \\
$\mathrm{yz}$
\end{tabular} & \begin{tabular}{|l|}
15 \\
90
\end{tabular} & $\begin{array}{l}23 \\
115\end{array}$ & \begin{tabular}{|l}
33 \\
132
\end{tabular} & $\begin{array}{l}19 \\
57\end{array}$ & $\begin{array}{l}20 \\
40\end{array}$ & $\begin{array}{l}10 \\
10\end{array}$ & $\begin{array}{l}120 \\
444\end{array}$ & 3.7 & III \\
\hline 3. & \begin{tabular}{|l|} 
Availabi \\
lity
\end{tabular} & \begin{tabular}{|l||}
$\mathrm{x}$ \\
$\mathrm{yx}$
\end{tabular} & \begin{tabular}{|l|}
25 \\
150
\end{tabular} & $\begin{array}{l}26 \\
130\end{array}$ & $\begin{array}{l}25 \\
100\end{array}$ & $\begin{array}{l}21 \\
63\end{array}$ & $\begin{array}{l}11 \\
22\end{array}$ & $\begin{array}{l}12 \\
12\end{array}$ & $\begin{array}{l}120 \\
477\end{array}$ & 3.975 & II \\
\hline 4. & $\begin{array}{l}\text { Brand } \\
\text { name }\end{array}$ & \begin{tabular}{|l||}
$x$ \\
$y x$
\end{tabular} & \begin{tabular}{|l|}
15 \\
90
\end{tabular} & $\begin{array}{l}26 \\
130\end{array}$ & $\begin{array}{l}19 \\
76\end{array}$ & $\begin{array}{l}19 \\
57\end{array}$ & $\begin{array}{l}22 \\
44\end{array}$ & \begin{tabular}{|l}
18 \\
18
\end{tabular} & $\begin{array}{l}120 \\
415\end{array}$ & 3.458 & IV \\
\hline 5. & $\begin{array}{l}\text { Health } \\
\text { Factor }\end{array}$ & \begin{tabular}{|l||}
$x$ \\
$y x$
\end{tabular} & \begin{tabular}{l|}
16 \\
96
\end{tabular} & $\begin{array}{l}19 \\
95\end{array}$ & $\begin{array}{l}9 \\
36\end{array}$ & $\begin{array}{l}17 \\
51\end{array}$ & $\begin{array}{l}31 \\
62\end{array}$ & $\begin{array}{l}28 \\
28\end{array}$ & $\begin{array}{l}120 \\
368\end{array}$ & $\begin{array}{l}3 . \\
067\end{array}$ & V \\
\hline 6. & Taste & \begin{tabular}{|l||}
$x$ \\
$y x$
\end{tabular} & \begin{tabular}{|l|}
43 \\
258
\end{tabular} & $\begin{array}{l}9 \\
45\end{array}$ & $\begin{array}{l}17 \\
68\end{array}$ & $\begin{array}{l}27 \\
81\end{array}$ & \begin{tabular}{|l|}
9 \\
18
\end{tabular} & \begin{tabular}{|l}
15 \\
15
\end{tabular} & $\begin{array}{l}120 \\
485\end{array}$ & 4.042 & I \\
\hline
\end{tabular}

\section{RESULT:}

From the above table, it is inferred that taste is the prime factor for selecting particular brand and hence it is in the first position, availability is the next reason for selecting particular brand and hence it is in the second position, followed by fair price in the third rank, brand name, health factor, better quality is in fourth, fifth and sixth ranks respectively.

\section{WEIGHTED AVERAGE METHOD}

\section{PRICE OF GINGERY OIL}

\begin{tabular}{|c|c|c|c|}
\hline SNo & Price of gingelly oil & No of Respondents & Percentage \\
\hline T. & Tery low & 6 & $5 \%$ \\
\hline 2. & Low & 16 & $13.33 \%$ \\
\hline 3. & Fair & 60 & $50 \%$ \\
\hline 74 & Hiligh & $\overline{30}$ & $\overline{25 \%}$ \\
\hline $\bar{j}$ j. & Very high & $\overline{8}$ & $6.67 \%$ \\
\hline & Total & 120 & $100 \%$ \\
\hline
\end{tabular}

Source: compiled from questionnaire
Where, IV $=$ Assumed arerage, $X=N_{0}$ of Respondent

\begin{tabular}{|c||c||c||c||}
\hline \hline SNl & X & II & ITX \\
\hline \hline 1. & 6 & 5 & 30 \\
\hline \hline 2. & 16 & 4 & 64 \\
\hline \hline 3. & 60 & 3 & 180 \\
\hline \hline 4. & 30 & 2 & 60 \\
\hline \hline 5. & 8 & 1 & 8 \\
\hline \hline & 120 & 15 & 342 \\
\hline
\end{tabular}

Weighted Avergege XW $=342 / 20$

\section{Table value $=2.85 \approx 3$}

\section{RESULT:}

Based on weighted average the above table states that $60 \%$ of the respondents feel that the price charged for their brand gingelly oil is fair.

\section{CONCLUSION}

Health conscious is the most important attribute as expected by the respondents so if the manufacturer wants to retain the consumer and also to increase the sales they should maintain the quality level. Advertisement seems to be the most widely accepted source of awareness. Therefore, manufacturers can use this media to create or increase high brand knowledge among the homemakers.Now-a-days one of the problem faced by the marketer is duplication in branded oils in the market, which will spoil not only the brand image also the health of consumers. To overcome such problem manufacturer must frequently change the outlook, design of the package of the oil.Every business is based on understanding the consumer and providing the kind of products they prefer. In the present day market, branding is inevitable and plays a vital role in demand creation. The branding is important, particularly in Indian markets, where numerous types of identical articles are marketed. Branding helps the manufacturer to create a good impression in the minds of most of the people.From this study it is clear that most of the homemakers prefer branded gingelly oil. The major factor that makes them to buy particular brand gingelly oil is advertisement, so it necessary to every manufacturer to invest more on advertisement to create awareness and to increase sales.

\section{REFERENCES}

1. S. \& Rabiyathul Basariya, S. 2019, "Influence of value analysis and cross training in industry", International Journal of Engineering and Advanced Technology, vol. 8, no. 6, pp. 1810-1811.

2. Velvizhi, R., Sri Gowtham, S. \& Jeya Priya, D. 2019, "Examination of early feedbacks for effective product retailing on E-commerce websites", International Journal of Engineering and Advanced Technology, vol. 8, no. 6 Special Issue 2, pp. 703-706. 
3. Anuradha, C., Pothumani, S. \& Kavitha, R. 2019, "A novel method towards E-commerce", International Journal of Engineering and Advanced Technology, vol. 8, no. 6 Special Issue 2, pp. 535-538.

4. Thomas, J. \& Rabiyathul Basariya, S. 2019, "A study on the issues of financial ratio analysis", Indian Journal of Public Health Research and Development, vol. 10, no. 3, pp. 1079-1081.

5. Ramachandran, S. \& Rabiyathul Basariya, S. 2019, "Online marketing study on customer satisfaction and relationship", Indian Journal of Public Health Research and Development, vol. 10, no. 3, pp. 1072-1078.

6. Priya, R., Vinothini, G. \& Cor Jesu, C.D. 2019, "The mentor-protégé relationship for professional growth", Journal of Advanced Research in Dynamical and Control Systems, vol. 11, no. 9 Special Issue, pp. 1110-1119.

7. Jannifer Rani, N., Bina Pani, S. \& Nimisha, N.S. 2019, "A study on money back polices available in LIC", Journal of Advanced Research in Dynamical and Control Systems, vol. 11, no. 9 Special Issue, pp. 833-839.

8. Saillaja, V., Jhansi Rani, K. \& Catherine, R. 2019, "Global marketing management planning and organization", Journal of Advanced Research in Dynamical and Control Systems, vol. 11, no. 9 Special Issue, pp. 489-493.

9. Saillaja, V., Jhansi Rani, K. \& Catherine, R. 2019, "The new phase of marketing information system", Journal of Advanced Research in Dynamical and Control Systems, vol. 11, no. 9 Special Issue, pp. 482-488.

10. Thoufiqulla \& Raju, D.V. 2019, "Perception of indian investor towards investment in mutual funds with special reference to mip funds", Journal of Advanced Research in Dynamical and Control Systems, vol. 11, no. 5, pp. 177-183.

11. Jasmine, K.R.M. \& Basariya, S.R. 2018, "A study on the customers benefits on mutual funds", International Journal of Civil Engineering and Technology, vol. 9, no. 4, pp. 45-48.

12. Vasanthi, S. \& Basariya, S.R. 2019, "Pros and cons of on the job training versus off the job training", International Journal of Scientific and Technology Research, vol. 8, no. 10, pp. 671-674.

13. Pavithra, J. \& Ganesan, M. 2016, "A study on awareness and impact of micro-financial schemes", International Journal of Applied Business and Economic Research, vol. 14, no. 8, pp. 5449-5460.

14. Pavithra, J., Dilli Babu, P. \& Ambuli, T.V. 2014, "A study on budgetary control at Maruti Service Masters, Chennai", International Journal of Applied Business and Economic Research, vol. 12, no. 2, pp. 151-161.

15. Gunaraja, T.M. \& Venkatrama Raju, D. 2018, "Determining factors of organisational climate with reference to leadership styles", International Journal of Mechanical Engineering and Technology, vol. 9, no. 9, pp. 1327-1332.

16. Gunaraja, T.M. \& Venkatrama Raju, D. 2018, "The role of job satisfaction and training of employees in determining organisational climate of a selected industry", International Journal of Civil Engineering and Technology, vol. 9, no. 8, pp. 1266-1269.

17. Aarathy, T.S. \& Raju, D.V. 2018, "Performance appraisal and its effects on employees with respect to it sector in Chennai city", International Journal of Civil Engineering and Technology, vol. 9, no. 6, pp. 1535-1538.

18. Aarathy, T.S. \& Raju, D.V. 2018, "Employee perception towards performance appraisal system in IT sector", International Journal of Mechanical Engineering and Technology, vol. 9, no. 5, pp. 131-135.

19. Porselvi, W., Jublee, D. \& Sivanesan, G. 2018, "A study on factors influencing adoption of technology and innovation in banking industry, tamilnadu, India", International Journal of Mechanical Engineering and Technology, vol. 9, no. 5, pp. 789-800.

20. Akessa, G.M. and Dhufera, A.G., 2015. Factors That Influences Students Academic Performance: A Case of Rift Valley University, Jimma, Ethiopia. Journal of Education and Practice, 6(22), pp.55-63.

21. Miller, G. and Shih, C.C., 1999. A faculty assessment of the academic rigor of on-and off-campus courses in agriculture. Journal of Agricultural Education, 40, pp.57-65.

22. Tsinidou, M., Gerogiannis, V. and Fitsilis, P., 2010. Evaluation of the factors that determine quality in higher education: an empirical study. Quality Assurance in education, 18(3), pp.227-244.

23. Farooq, M.S., Chaudhry, A.H., Shafiq, M. and Berhanu, G., 2011. Factors affecting students' quality of academic performance: a case of secondary school level. Journal of quality and technology management, 7(2), pp.1-14.

24. Fitsilis, P., Gerogiannis, V. and Anthopoulos, L., 2014. Ontologies for software project management: a review. Journal of Software Engineering and Applications, 7(13), p.1096.

\section{AUTHORS PROFILE}

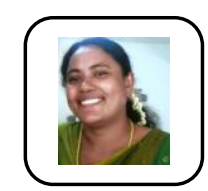

W.Porselvi, Assistant Professor, Department Of Science and Humanities,Bharath Institution Of Higher Education And Research TamilNadu,India

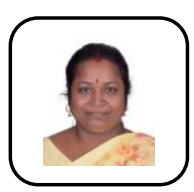

R.Vasuki, Assistant Professor, Department Of Science and Humanities,Bharath Institution Of Higher Education And Research TamilNadu,India.

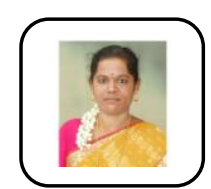

G.Anandhi Assistant Professor, Department Of Science and Humanities,Bharath Institution Of Higher Education And Research TamilNadu,India 